\title{
The effect of heparin on the cell cycle in human B-lymphoblasts: An in vitro study
}

\section{Heparinin insan B-lenfositlerinin hücre döngüsüne etkisi: Bir in vitro çalışma}

\author{
Ayşe Aksoy ${ }^{1}$, Erol Erduran², Yavuz Tekelioğlu, Mehmet Mutlu4 ${ }^{4}$, Yusuf Gedik ${ }^{5}$ \\ ${ }^{1}$ Department of Pediatrics, Division of Child Neurology, Karadeniz Technical University, Trabzon, Turkey \\ 2Department of Hematology, Karadeniz Technical University, Trabzon, Turkey \\ ${ }^{3}$ Department of Histology and Embryology, Karadeniz Technical University, Trabzon, Turkey \\ ${ }^{4}$ Department of Pediatrics, Karadeniz Technical University, Trabzon, Turkey \\ ${ }^{5}$ Department of Cardiology, Karadeniz Technical University, Trabzon, Turkey
}

\begin{abstract}
Objective: Heparin has been shown to be a strong inhibitor of the proliferation of several cell types. In this in vitro study, we investigated whether different heparin concentrations can affect the cell cycle of lymphoblasts in newly diagnosed acute lymphoblastic leukemia (ALL) patients.

Materials and Methods: Lymphoblasts were incubated in different heparin concentrations $(0,10,20 \mathrm{U} /$ $\mathrm{ml}$ ), and the percentages of lymphoblasts in each phase of the cell cycle were simultaneously measured by flow cytometry at 0,1 , and 2 hours (h).

Results: The percentages of lymphoblasts at the G2/M and S phases were significantly increased in 20 $\mathrm{U} / \mathrm{ml}$ heparin concentration at $1 \mathrm{~h}$ compared to $0 \mathrm{U} / \mathrm{ml}$ (without heparin) concentration. We demonstrated that heparin increases the percentages of lymphoblasts in the $S$ and G2/M phases in a concentration- and time-dependent manner.

Conclusion: It was shown that heparin expands the proliferation of lymphoblasts by increasing the transition to G2/M and S phases and the S-phase fraction ratio. Heparin thus appears promising for its contribution to new treatment fields such as by providing a synergistic effect with chemotherapeutic drugs. (Turk J Hematol 2010; 27: 242-9)
\end{abstract}

Key words: Cell cycle, heparin, leukemia

Received: December 11, 2009

Accepted: April 30, 2010

\section{Özet}

Amaç: Heparin, çeşitli hücre tiplerinde proliferasyonun güçlü bir inhibitörü olduğu gösterilmiştir. Bu in vitro çalışmada; akut lenfoblastik lösemi (ALL) tanısı alan hastalarda farklı heparin konsantrasyonlarının lenfoblast hücre döngüsündeki fazlara etkisi araştırıldı.

Yöntem ve Gereçler: Lenfoblastlar 0 (heparinsiz), 10 ve $20 \mathrm{U} / \mathrm{mL}$ heparin konsantrasyonlarına maruz bırakılarak 0,1 ve 2 saatlerde lenfoblastların hücre döngüsü oranları FCM ile ölçüldü. 
Bulgular: Lenfoblastlar, $0 \mathrm{U} / \mathrm{mL}$ heparinsiz konsantrasyonuna göre; $20 \mathrm{U} / \mathrm{mL}$ heparin konsantrasyonunun 1. saatinde en fazla olmak üzere $G 2 / M$ ve $S$ döngüsü anlamlı derecede artmıştır. Heparinin doza ve zamana bağlı olarak lenfoblastların $G 2 / M$ ve $S$ fazlarında artışa neden olduğunu gösterdik. Sonuç: Heparin, hücre döngüsünde G2/M ve $S$ fazına geçişi artırarak lenfoblastlarda proliferasyonu artırdığı gösterildi. Böylece heparinin, kemoterapi ilaçları ile sinerjistik etki sağlayarak yeni tedavi alanlarına olası katkıları umut verici olarak görünüyor. Bu ön çalışmamızın sonuçları, heparinin lenfoblastlardaki proliferatif etkisini araştırmak amacı ile daha ayrıntılı ve kapsamlı çalışma yapılması gerektiği gösterir. (Turk J Hematol 2010; 27: 242-9)

Anahtar kelimeler: Hücre siklusu, heparin, lösemi

\section{Introduction}

Heparin, which is generally used as an anticoagulant but has been shown to have additional biological activities, was determined in several clinical trials to have an effect on malignancies. The activities of heparin include anticoagulant, tissue factor pathways inhibitor release, heparinase inhibition, selectin-mediated interaction inhibition, modulation of the activity of some proteases and extracellular matrix components, and growth factor binding [1-6].

Leukemia cells were found sensitive to chemotherapeutic agents that either interfere with the cell cycle or cause apoptosis [7-9]. Some anti-cancer reagents cause cell death through interfering with the processes of the cell cycle, while others cause cell death by apoptosis, which plays an important role in the balance between cell replication and cell death [7,10]. Almost all conventional anticancer drugs are primarily effective against rapidly dividing cells [11]. Compared with proliferating lymphocytes, a 500-fold higher concentration of chemotherapeutic drug is required to kill resting cells [12]. In initial acute lymphoblastic leukemia (ALL), a higher fraction of proliferating cells seems to result in a higher efficacy of the chemotherapeutic drug targeting the cell division cycle. Interestingly, at first presentation of childhood ALL, the prognostic value of the proliferative capability of lymphoblasts remains controversial, and there is no clear evidence of an association with prognosis [13-15]. However, in in vitro experiments, an increased proliferation rate was associated with good response to treatment [15].

The S-phase fraction (SPF) measures the percentage of a given cycling subpopulation between G0/G1 and G2/M phases, and it reflects cell proliferation [16]. The SPF has been studied in different malignancies including ALL for the purpose of classification or prognosis. It has been proven to be a useful prognostic marker in types of solid cancers and leukemia [14,17-19]. However, contradictory results have been reported concerning the prognostic value of the SPF of leukemia cells [13-15].

To date, no study dealing with the proliferative activity of heparin in human lymphoblasts has been undertaken. In this in vitro study, we investigated whether heparin can affect proliferation of lymphoblasts in newly diagnosed ALL patients. We also attempted to establish by flow cytometry (FCM) which phase in the cell cycle of the lymphoblasts can be considered heparin-sensitive. This was determined by analyzing the correlation between the SPFs and the effect of heparin on the lymphoblast cell cycle.

\section{Materials and Methods}

Twelve children ( 8 girls, 4 boys; age: $2-15$ years) with newly diagnosed ALL (all had B-cell leukemia) were included in the study with the written consent of their parents. The clinical features of the 12 patients are shown in Table 1. Diagnosis of the patients was done according to the findings of complete blood counts, peripheral and bone marrow aspiration (BMA) smears, histochemical staining of BMA smears, and FCM analysis (Coulter Epics Elite ESP Flow Cytometry) of BMA materials. ALL was diagnosed by examining a lymphoblast population of more than $25 \%$ in the BMA smears. No patients had Philadelphia chromosome.

\section{Cell typing}

CD3 PE (Coulter PN IM1282), CD7 FITC (Coulter PN IM0585), CD10 FITC (Coulter PN IM0471), CD13 FITC (Coulter PN IM0778), CD14 FITC (Coulter PN IM0650), CD19 FITC (Coulter PN IM1284), CD20 FITC (Coulter PN IM1455), CD33 FITC (Coulter PN IM1179), CD45 FITC (Coulter PN IM0782) and MPO FITC (Coulter PN IM1874) monoclonal antibodies 
Table 1. Clinical features of children with acute lymphoblastic leukemia

\begin{tabular}{|c|c|c|c|c|c|c|}
\hline Patient no & Sex & Age (yr) & Stage of disease & $\begin{array}{c}\text { WBC } \\
\left(\times 10^{3} / \mu \mathrm{l}\right)\end{array}$ & $\begin{array}{c}\text { \% Blast } \\
(\mathrm{BM})\end{array}$ & Immunophenotype \\
\hline 1 & $\mathrm{~F}$ & 4 & Diagnosis & 1.2 & 98 & $\mathrm{CD}_{10}, \mathrm{CD}_{19}, \mathrm{CD}_{20}$ \\
\hline 2 & $\mathrm{~F}$ & 3 & Diagnosis & 120.0 & 88 & $\mathrm{CD}_{10}, \mathrm{CD}_{19}, \mathrm{CD}_{20}$ \\
\hline 3 & $\mathrm{~F}$ & 3 & Diagnosis & 25.2 & 96 & $\mathrm{CD}_{10}, \mathrm{CD}_{19}$ \\
\hline 4 & M & 5 & Diagnosis & 2.8 & 95 & $\mathrm{CD}_{10}, \mathrm{CD}_{19}$ \\
\hline 5 & $\mathrm{~F}$ & 2 & Diagnosis & 7.8 & 88 & $\mathrm{CD}_{10}, \mathrm{CD}_{19}$ \\
\hline 6 & $\mathrm{M}$ & 7 & Diagnosis & 44.7 & 89 & $\mathrm{CD}_{10}$ \\
\hline 7 & $\mathrm{~F}$ & 4 & Diagnosis & 30.3 & 95 & $\mathrm{CD}_{10}, \mathrm{CD}_{20}$ \\
\hline 8 & $\mathrm{M}$ & 14 & Diagnosis & 2.7 & 97 & $\mathrm{CD}_{10}$ \\
\hline 9 & $\mathrm{~F}$ & 15 & Diagnosis & 127.0 & 90 & $\mathrm{CD}_{19}, \mathrm{CD}_{20}$ \\
\hline 10 & $\mathrm{~F}$ & 2 & Diagnosis & 13.1 & 90 & $\mathrm{CD}_{10}$ \\
\hline 11 & M & 6 & Diagnosis & 99.2 & 88 & $\mathrm{CD}_{10}$ \\
\hline 12 & $\mathrm{~F}$ & 5 & Diagnosis & 9.7 & 98 & $\mathrm{CD}_{19}, \mathrm{CD}_{20}$ \\
\hline
\end{tabular}

WBC: Leukocyte counts at diagnosis; BM: Bone marrow

were used for the diagnosis of ALL. All patients had monoclonal antibody positivity for B-cell leukemia.

\section{Separation of Blast Cells}

Bone marrow aspiration (BMA) materials were drawn into a tube with ethylene diamine tetraacetate (EDTA). The same quantities of phosphatebuffered saline (PBS) and the BMA sample were added into the tube. The sample was stirred, and waited for 30 minutes (min) at room temperature. Buffy coat obtained from the upper surface of the specimen was added onto Ficoll-Hypaque 1077 (lymphocyte separation medium Gibco BRL 1301012 , Grand Island, NY) and centrifuged at $700 \mathrm{~g}$ for 30 min. Mononuclear cells containing $\geq 90 \%$ lymphoblasts were obtained from the upper surface of the specimen and washed twice with PBS to exclude debris. The blast cells were suspended at a concentration of 3-5 $\times 10^{5}$ cells/ml in RPMI with L-glutamine without sodium bicarbonate medium (Sigma R-6504, Miami, FL). $100 \mathrm{ml}$ of each material was studied for immunotyping by FCM. The remaining amount of each sample was kept at $-80^{\circ} \mathrm{C}$ approximately five-seven months until the study was performed. Viability of lymphoblasts was again determined after having the samples using acridine orange. Lymphoblasts with viability higher than 70\% were used in the study.

Pure heparin was used in the study (Sigma Biochemicals and Reagents-2001 Catalog, Sigma H 3149). The purity and activity of heparin were Grade $\mathrm{I}, \geq 140 \mathrm{USP}$ unit/mg. The heparin did not include the additional stabilizing agents. The blast cell suspensions were thawed at room temperature. No heparin $(0 \mathrm{U} / \mathrm{ml})$ or different heparin concentrations $(10,20 \mathrm{U} / \mathrm{ml})$ were added on the blast cells $(1 \mathrm{ml})$. Each tube included different heparin concentrations and was divided into three different tubes. All the samples were processed with a Coulter DNA-prep reagent kit (CN: 640445) at 0, 1, and 2 hours (h). The DNA-prep reagent kit contained DNA prep-LPR solution $(<0.1 \%$ potassium cyanide, $<0.1$ sodium nitride, nonionic detergents, saline, and stabilizers) and the DNA-prep stain $\left(50 \mu \mathrm{g} / \mathrm{ml}\right.$ propidium iodide [PI], $<0.5 \% \mathrm{NaN}_{3}$, saline, and stabilizers). The blast membranes were pored by the DNA-prep LPR solution, and RNAs and DNAs of the blasts were stained with PI. Stained RNAs were removed from the medium by RNAse; therefore, DNA content was marked by PI. The aliquots were taken following 0,1 , and $2 \mathrm{~h}$, and FCM analyses were carried out for cell cycle of the blast cells in a Coulter Epics Elite Flow Cytometer (Multicycle DNA, Phoenix Flow Systems, San Diego, CA). The FCM analyses were immediately done within 3-5 seconds after adding no heparin or different heparin concentrations $(0,10$ and $20 \mathrm{U} / \mathrm{ml})$ on to the blasts.

Flow cytometric (FCM) analyses could not be performed in 10 and $20 \mathrm{U} / \mathrm{ml}$ heparin concentrations at $3 \mathrm{~h}$ because the samples were seen to have transformed into a gelatinous substance. A gelatinous substance similarly developed following the addition of higher heparin concentrations (30 and $50 \mathrm{U} / \mathrm{ml}$ ) into the lymphoblast samples. 
The percentages of the cells in the G0/G1, G2/M and $\mathrm{S}$ phases were determined from an analysis using the PEAK computer program, generously provided by Dr. Phillip Dean [20]. Since only samples that contained more than $80 \%$ leukemic cells were included, the lymphoblast proliferative activity was expressed in terms of the calculated percentage of cells in the $\mathrm{S}$ phase of their cycle.

The fraction of cells in the G0/G1, S and G2/M phases of the cell cycle is mathematically determined from the DNA distribution. The SPF is the fraction of the total cell population in the $S$ phase of the cell cycle [16].

$$
\mathrm{SPF}=\frac{\mathrm{S}}{\mathrm{G}_{0} / \mathrm{G}_{1}+\mathrm{S}+\mathrm{G}_{2} / \mathrm{M}} \times 100
$$

\section{Statistical Analysis}

Data obtained from FCM and fluorometrik measurements were analyzed by the SPSS version 10.0 statistical package program. Variance analysis was used in the repeated measurements and the comparison of groups. The normal distribution of the data was assessed by Kolmogorov-Smirnov test. Paired t test (post hoc) was used to determine the statistically significant differences between measurements using different heparin concentrations. Results were calculated as arithmetic mean \pm standard deviation $(\mathrm{x} \pm \mathrm{SD})$.

\section{Results}

The cell cycle analyses were performed without heparin and with heparin at varying concentrations $(0,10$ and $20 \mathrm{U} / \mathrm{ml})$ at 0,1 , and $2 \mathrm{~h}$ after adding heparin on to the lymphoblasts. However, the samples with heparin were seen to transform into a gelatinous substance after $2 \mathrm{~h}$; hence, FCM analysis could not be performed.

The mean percentage of blast cells in the G0/G1 phase in different heparin concentrations at 0 (without heparin), 1 , and $2 \mathrm{~h}$ are shown in Table 2 . In $0 \mathrm{U} /$ $\mathrm{ml}$ (without heparin) concentration, the mean percentage of blast cells in the G0/G1 phase at $2 \mathrm{~h}$ was significantly lower than those at $0 \mathrm{~h}$ and $1 \mathrm{~h}$ $(p<0.001)$. The highest percentage of blast cells in the $\mathrm{G} 0 / \mathrm{G} 1$ phase was established in $0 \mathrm{U} / \mathrm{ml}$ (without heparin) at $0 \mathrm{~h}$. The lowest percentage of blast cells in the $\mathrm{G} 0 / \mathrm{G} 1$ phase was determined in $20 \mathrm{U} / \mathrm{ml}$ heparin level at $1 \mathrm{~h}$. The mean percentage of blast cells in the $\mathrm{G} 0 / \mathrm{G} 1$ phase in $20 \mathrm{U} / \mathrm{ml}$ heparin concentration at $1 \mathrm{~h}$ was significantly lower than in $0 \mathrm{U} / \mathrm{ml}$ (without heparin) and $10 \mathrm{U} / \mathrm{ml}$ heparin concentrations at $1 \mathrm{~h}(\mathrm{p}<0.001)$, and in $20 \mathrm{U} / \mathrm{ml}$ heparin concentration at $0 \mathrm{~h}(\mathrm{p}<0.001)$. There were significant differences between the percentage of the lymphoblasts in $20 \mathrm{U} / \mathrm{ml}$ and $10 \mathrm{U} / \mathrm{ml}$ heparin concentrations and $0 \mathrm{U} / \mathrm{ml}$ (without heparin) at $2 \mathrm{~h}(\mathrm{p}<0.001)$.

The mean percentage of blast cells in the G2/M phase in the different heparin concentrations at 0,1 , and $2 \mathrm{~h}$ are shown in Table 3 . There were significant differences in the mean percentage of blast cells in the $\mathrm{G} 2 / \mathrm{M}$ phase in $0 \mathrm{U} / \mathrm{ml}$ (without heparin) concentration at 0,1 , and $2 \mathrm{~h}(\mathrm{p}<0.001)$. The lowest percentage of blast cells in the $\mathrm{G} 2 / \mathrm{M}$ phase was determined in $0 \mathrm{U} / \mathrm{ml}$ without heparin concentration at $2 \mathrm{~h}$. The highest percentage of blast cells in the G2/M phase was determined in $20 \mathrm{U} / \mathrm{ml}$ heparin level at $1 \mathrm{~h}$. The mean percentage of blast cells in the G2/M phase in $20 \mathrm{U} / \mathrm{ml}$ heparin concentration at $1 \mathrm{~h}$ was significantly higher than those in $0 \mathrm{U} / \mathrm{ml}$ and $10 \mathrm{U} / \mathrm{ml}$ heparin concentrations at $1 \mathrm{~h}(\mathrm{p}<0.001)$, and in $20 \mathrm{U} / \mathrm{ml}$ heparin concentration at $0 \mathrm{~h}(\mathrm{p}<0.003)$. The mean percentage of blast cells in $20 \mathrm{U} / \mathrm{ml}$ heparin level at 1

Table 2. Percentages of lymphoblasts in the G0/G1 phase in $0 \mathrm{U} / \mathrm{ml}$ (without heparin), 10 and $20 \mathrm{U} / \mathrm{ml}$ heparin concentrations at 0,1 , and 2 hours (\%, mean $\pm \mathrm{SD}$, min.-max.)

\begin{tabular}{lccc}
\hline Heparin & \multicolumn{3}{c}{ Time (hour) } \\
& $\mathbf{0}$ & $\mathbf{1}$ & $\mathbf{2}$ \\
\hline $0 \mathrm{U} / \mathrm{ml}$ & $97.80 \pm 0.51^{\mathrm{a}}$ & $97.72 \pm 0.47^{\mathrm{d}}$ & $97.62 \pm 0.48 \mathrm{~g}$ \\
& $97.0-98.5$ & $97.0-98.3$ & $96.9-98.2$ \\
$10 \mathrm{U} / \mathrm{ml}$ & $85.38 \pm 4.3^{\mathrm{b}}$ & $85.54 \pm 2.06^{\mathrm{e}}$ & $90.77 \pm 0.81^{\mathrm{h}}$ \\
& $78.9-92.0$ & $82.4-89.0$ & $90.0-92.0$ \\
$20 \mathrm{U} / \mathrm{ml}$ & $88.38 \pm 3.12^{\mathrm{c}}$ & $76.91 \pm 4.58^{\mathrm{f}}$ & $78.34 \pm 2.12^{\mathrm{i}}$ \\
& $83.3-92.0$ & $69.6-84.5$ & $74.9-81.0$
\end{tabular}

a-b, a-c, c-f, c-i, d-e, d-f, e-h, e-f, g-h, g-i, h-i: p<0.001, b-h: p<0.001

Table 3. Percentages of lymphoblasts in the G2/M phase in $0 \mathrm{U} / \mathrm{ml}$ (without heparin), 10 and $20 \mathrm{U} / \mathrm{ml}$ heparin concentrations at 0,1 , and 2 hours (\%, mean $\pm \mathrm{SD}$, min.-max.)

\begin{tabular}{lccc}
\hline Heparin & $\mathbf{0}$ & Time (hour) & $\mathbf{1}$ \\
\hline $0 \mathrm{U} / \mathrm{ml}$ & $1.16 \pm 0.42^{\mathrm{a}}$ & $1.18 \pm 0.42^{\mathrm{d}}$ & $1.08 \pm 0.43 \mathrm{~g}$ \\
& $0.5-1.9$ & $0.5-1.9$ & $0.4-1.8$ \\
$10 \mathrm{U} / \mathrm{ml}$ & $7.24 \pm 1.9 \mathrm{~b}$ & $4.50 \pm 1.74 \mathrm{e}$ & $3.00 \pm 0.76 \mathrm{~h}$ \\
& $4.1-10.1$ & $1.8-7.4$ & $1.3-4.0$ \\
$20 \mathrm{U} / \mathrm{ml}$ & $6.00 \pm 1.95^{\mathrm{c}}$ & $10.21 \pm 3.49^{\mathrm{f}}$ & $9.37 \pm 2.65^{\mathrm{i}}$ \\
& $3.0-9.0$ & $5.4-18.4$ & $4.9-13.0$
\end{tabular}

a-b, a-c, b-e, b-h, d-f, e-f, g-i, h-i: $\mathrm{p}<0.001$, c-f: $\mathrm{p}<0.003$, d-e: $\mathrm{p}<0.003$, c-i, e-h: p $<0.006$, g-h: $\mathrm{p}<0.0$ 
$\mathrm{h}$ was significantly higher than those in $0 \mathrm{U} / \mathrm{ml}$ (without heparin) and $10 \mathrm{U} / \mathrm{ml}$ heparin levels $(\mathrm{p}<0.001)$.

The mean percentage of blast cells in the $S$ phase in different heparin concentrations at 0,1 , and $2 \mathrm{~h}$ are shown in Table 4 . The mean percentage of blast cells in the $\mathrm{S}$ phase in $0 \mathrm{U} / \mathrm{ml}$ (without heparin) concentration was the same at 0,1 , and $2 \mathrm{~h}$. The lowest percentage of blast cells in the $\mathrm{S}$ phase was determined in $0 \mathrm{U} / \mathrm{ml}$ (without heparin) concentration. The highest percentage of blast cells in the $\mathrm{S}$ phase was determined in $20 \mathrm{U} / \mathrm{ml}$ heparin concentration at $1 \mathrm{~h}$. The mean percentage of the blast cells in the S phase in $20 \mathrm{U} / \mathrm{ml}$ heparin concentration at $1 \mathrm{~h}$ was significantly higher than in $0 \mathrm{U} / \mathrm{ml}$ (without heparin) and $10 \mathrm{U} / \mathrm{ml}$ heparin concentrations ( $p<0.001, p<0.006$, respectively) and in $20 \mathrm{U} /$ $\mathrm{ml}$ heparin concentration at $0 \mathrm{~h}(\mathrm{p}<0.001)$. There were significant differences between the percentages of the blast cells in $20 \mathrm{U} / \mathrm{ml}$ and $10 \mathrm{U} / \mathrm{ml}$, and $20 \mathrm{U} / \mathrm{ml}$ and $0 \mathrm{U} / \mathrm{ml}$ heparin levels in $\mathrm{S}$ phase at $1 \mathrm{~h}$ $(p<0.001)$, and the highest percentage of the lymphoblasts in S phase at $2 \mathrm{~h}$ was detected in $20 \mathrm{U} / \mathrm{ml}$ heparin level.

In the $0 \mathrm{U} / \mathrm{ml}$ (without heparin) concentration at $0 \mathrm{~h}, 97.80 \%$ of the lymphoblasts were in the $\mathrm{G} 0 / \mathrm{G} 1$ phase, and this value dropped to $76.91 \%$ in $20 \mathrm{U} / \mathrm{ml}$ heparin concentration at $1 \mathrm{~h}(\mathrm{p}<0.001)$. Similarly, at $0 \mathrm{~h}, 1.16 \%$ of the lymphoblasts were in $\mathrm{G} 2 / \mathrm{M}$ phase, and this value increased to $10.21 \%$ in $20 \mathrm{U} /$ $\mathrm{ml}$ heparin concentration at $1 \mathrm{~h}(\mathrm{p}<0.001)$. Also at $0 \mathrm{~h}, 1.03 \%$ of the lymphoblasts were in $\mathrm{S}$ phase, and this value increased to $13.63 \%$ in $20 \mathrm{U} / \mathrm{ml}$ heparin concentration at $1 \mathrm{~h}(\mathrm{p}<0.001)$. G0/G1 phase cell population decreased while G2/M and S phase cells increased in $10 \mathrm{U} / \mathrm{ml}$ and $20 \mathrm{U} / \mathrm{ml}$ concentrations at 1 and $2 \mathrm{~h}$ compared to cell populations at $0 \mathrm{~h}(\mathrm{p}<0.001)$.

\begin{tabular}{|c|c|c|c|}
\hline \multirow[t]{2}{*}{ Heparin } & \multicolumn{3}{|c|}{ Time (hour) } \\
\hline & $\mathbf{0}$ & 1 & 2 \\
\hline \multirow[t]{2}{*}{$0 \mathrm{U} / \mathrm{ml}$} & $1.03 \pm 0.60 \mathrm{a}$ & $1.03 \pm 0.60 \mathrm{~d}$ & $1.03 \pm 0.60 \mathrm{~g}$ \\
\hline & $0.2-2.0$ & $0.2-2.0$ & $0.2-2.0$ \\
\hline \multirow[t]{2}{*}{$10 \mathrm{U} / \mathrm{ml}$} & $7.43 \pm 3.61^{\mathrm{b}}$ & $10.12 \pm 2.71^{\mathrm{e}}$ & $6.22 \pm 0.95^{\mathrm{h}}$ \\
\hline & $3.0-14.4$ & $7.0-15.3$ & $5.0-7.9$ \\
\hline \multirow[t]{2}{*}{$20 \mathrm{U} / \mathrm{ml}$} & $5.45 \pm 2.31^{\mathrm{c}}$ & $13.63 \pm 3.47^{f}$ & $12.11 \pm 2.73^{\mathrm{i}}$ \\
\hline & $2.2-7.5$ & $10.0-21.4$ & $9.9-17.4$ \\
\hline
\end{tabular}

a-b, a-c, c-f, c-i, d-e, e-h, d-f, g-h, g-i, h-i: p<0.001, e-f: p<0.006
The SPF was determined in the $0 \mathrm{U} / \mathrm{ml}$ (without heparin), $10 \mathrm{U} / \mathrm{ml}$ and $20 \mathrm{U} / \mathrm{ml}$ heparin concentrations at 0,1 and $2 \mathrm{~h}$, with values ranging from $1-13.6 \%$ (data not shown). While the SPF values in the $0 \mathrm{U} / \mathrm{ml}$ (without heparin) at $0 \mathrm{~h}, 1 \mathrm{~h}$ and $2 \mathrm{~h}$ were $1 \%$, the highest SPF value was $13.6 \%$ in the $20 \mathrm{U} / \mathrm{ml}$ heparin concentration at $1 \mathrm{~h}$. We found a statistically significant difference in the mean SPF ratio in the $20 \mathrm{U} / \mathrm{ml}$ heparin concentration at $1 \mathrm{~h}$ compared to the other groups $(\mathrm{p}<0.05)$.

Prominent alterations in the cell cycle distribution were observed in $20 \mathrm{U} / \mathrm{ml}$ heparin concentration at $1 \mathrm{~h}$. There was a movement of lymphoblast cells from $\mathrm{G} 0 / \mathrm{G} 1$ to $\mathrm{G} 2 / \mathrm{M}$ and $\mathrm{S}$ phases. The percentage of lymphoblasts in the $\mathrm{G} 0 / \mathrm{G} 1$ phase was decreased while the percentage of lymphoblasts in the $\mathrm{G} 2 / \mathrm{M}$ and $\mathrm{S}$ phases was increased in $20 \mathrm{U} / \mathrm{ml}$ heparin level at $1 \mathrm{~h}$. This study showed that the effect of heparin in the cell cycle of lymphoblasts was associated with a decrease in the percentage of $\mathrm{G} 0 / \mathrm{G} 1$ phase cells and an increase in the percentage of $\mathrm{G} 2 / \mathrm{M}$ and $\mathrm{S}$ phase cells in a dose- and timedependent manner. In other words, we found that heparin increases both the percentage of lymphoblast cells in $\mathrm{G} 2 / \mathrm{M}$ and $\mathrm{S}$ phases and the SPF ratio in $20 \mathrm{U} / \mathrm{ml}$ heparin level at $1 \mathrm{~h}$. The FCM histograms of lymphoblasts depicted characteristic DNA distributions in $0 \mathrm{U} / \mathrm{ml}$ (without heparin) and $20 \mathrm{U} / \mathrm{ml}$ heparin concentrations at $1 \mathrm{~h}$ in a patient (no: 6) with ALL [Figure 1(A) and (B)]. Comparisons of the percentages of the lymphoblastic cell populations in 0 $\mathrm{U} / \mathrm{ml}$ (without heparin) and $20 \mathrm{U} / \mathrm{ml}$ heparin levels in the $\mathrm{G} 0 / \mathrm{G} 1, \mathrm{~S}$ and $\mathrm{G} 2 / \mathrm{M}$ cell cycle phases at $1 \mathrm{~h}$ are shown in Figure 1(A) and 1(B), respectively.

\section{Discussion}

In the present study, we have demonstrated that heparin increases the percentages of lymphoblasts in the $\mathrm{S}$ and G2/M phases and the SPF ratio in a concentration- and time-dependent manner. This indicates that heparin may induce the proliferation of lymphoblasts by increasing the cell cycle percentages in the G2/M and S phases and the SPF ratio. To the best of our knowledge, no study has reported on the influence of heparin on the cell cycle of lymphoblasts and the correlation with the SPF.

Although previous works demonstrated that heparin could inhibit proliferation of hepatoma cells, vascular smooth muscle cells, renal mesangial cells, and cervical epithelial cells, we have shown that heparin induced lymphoblast proliferation by 
Aksoy et al.

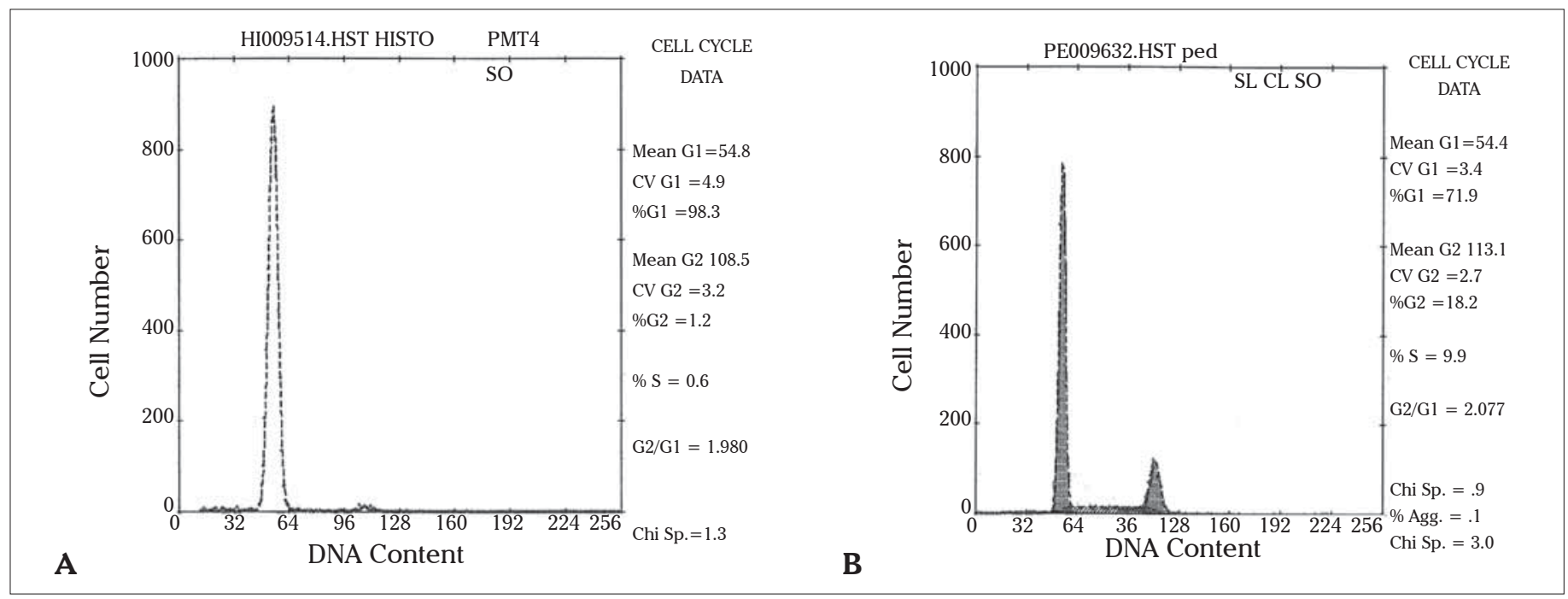

Figure 1(A) and (B). Comparison of the percentage of the lymphoblastic cell populations in $0 \mathrm{U} / \mathrm{ml}$ (without heparin) (A) and $20 \mathrm{U} / \mathrm{ml}$ (B) heparin levels in the G0/G1, S and G2/M cell cycle phases at 1 hour (respectively, left and right) (No: 6)

increasing the cell cycle percentages in the $\mathrm{S}$ and G2/M phases [1,21-24]. The antiproliferative activity of heparin has been linked to the blockage of the G1 phase of the cell cycle, and also reduces the number of cells entering the cycle from G1 [1,3,22,25,26]. Even though it is known from earlier studies that heparin has an antiproliferative effect on non-cancerous cells, it is quite interesting that it was shown in this study to increase proliferation in lymphoblasts. The mechanism responsible for these effects of heparin must be investigated in further studies. On the other hand, heparin causes apoptosis in human peripheral blood neutrophils, lymphoblasts and mononuclear cells, and indicates its apoptotic effect on lymphoblasts via extrinsic or intrinsic pathways [27-29].

We demonstrated in this study that the greatest proliferation effect of heparin and the highest SPF ratio were determined in $20 \mathrm{U} / \mathrm{ml}$ concentration at 1 h. Recent studies from Erduran et al. [30] determined that the greatest apoptotic effect of heparin on the lymphoblasts was detected in $20 \mathrm{U} / \mathrm{ml}$ concentration at $1 \mathrm{~h}$. The results of some recent studies were found to be concordant [28-30]. Apoptosis and proliferation are important regulators of normal development and homeostasis in the bone marrow. According to the knowledge gained in previous experimental studies, a greater regenerative capacity of hematopoiesis may be reflected by an increased rate of apoptosis and/or proliferation and therefore is associated with a more favorable outcome [31]. According to these results, we suggest that heparin may have a dual effect on lympho- blasts by stimulating apoptosis in a portion of them, while increasing proliferation in others by stimulating $\mathrm{S}$ and G2/M phases in the cell cycle. Whether or not this dual effect contributes to prognosis will require further investigation. We did not aim to show which molecular pathway is involved in the proliferative effect of heparin on the lymphoblast cell cycle. In view of the preliminary nature of our study, our purpose was only to establish whether or not heparin had any effect on the cell cycle of lymphoblasts. We believe that the relationship among heparin, cell cycle phases and apoptosis needs to be studied at the molecular level.

Chemotherapy agents may work in only one phase of the cycle (termed "cell-cycle specific") (e.g. azathioprine, cytosine arabinoside (Ara-C), hydroxyurea, and vincristine), or in all phases ('cellcycle nonspecific"). Many chemotherapeutic drugs are effective on the cells in the $\mathrm{S}$ phase of the cell cycle [8-11,32]. Bone marrow samples generally had a higher SPF ratio than blood samples in children with leukemia [33]. The relationship of leukemic blast proliferative activity to prognosis is controversial. Duque et al. [14] reported that the SPF was not prognostic for treatment response or response duration in acute leukemia in general. On the other hand, several studies reported that bone marrow SPFs of $>6 \%$ were strongly predictive of outcome in childhood ALL [33,34]. In contrast, Braess et al. [13] found that a high proliferative activity was associated with a higher complete remission rate in 187 patients with acute myeloblastic leukemia. On the other hand, it has been demonstrated that stimula- 
tion of cell proliferation of leukemia cells by pretreatment with growth factors (granulocyte colonystimulating factor, granulocyte-macrophage colonystimulating factor, interleukin-3) in combination with cycle-specific cytotoxic drugs as chemosensitizing agents could enhance in vitro sensitivity to some chemotherapeutic agents for killing of leukemic stem cells [35-38]. It was reported that an increased in vitro sensitivity to several chemotherapeutic drugs, such as vincristine and L-asparaginase, was related to higher SPF of lymphoblasts isolated from initial childhood ALL patients. Especially the SPF of pretreatment childhood ALL samples appeared to correlate with the in vitro sensitivity to several chemotherapeutic drugs [15]. Since increased proliferative activity may increase the sensitivity to chemotherapeutic drugs, pretreatment with growth factors prior to treatment with these proliferation-dependent drugs may increase the response rate in childhood acute leukemia. The increased proliferative effect of heparin on lymphoblasts will be important for its contribution to new treatment fields. Our results presented here indicate that heparin increases the proliferation of lymphoblasts in G2/M and $\mathrm{S}$ phases and the SPF. Heparin might increase the effect of chemotherapeutic drugs on lymphoblasts that are in the G2/M and S phases. Alternatively, heparin combined with chemotherapeutic agents might be a feasible approach to increase the effectiveness of the chemotherapy with relative specificity for the lymphoblasts, but these results should be tested in vivo. We lack data for comparison of the effect of heparin on various types and stages of leukemia.

Thromboembolism is a common finding in patients with malignancy and a well-recognized serious complication during chemotherapy, such as with Ara-C. Anticoagulation with heparin has also been suggested in children undergoing some kinds of ALL therapy [39]. Our results might suggest that pretreatment with heparin as a chemosensitizing approach could be useful for patients with ALL who are prone to thrombosis. The proliferative and apoptotic effects of heparin on lymphoblasts might present new opportunities in the treatment of childhood ALL. This study provides pilot data for a future randomized trial of the use of heparin during ALL therapy for the prevention of some chemotherapeutic agent-associated thrombotic events.

In conclusion, in addition to its anticoagulant effect, heparin might be useful in children with ALL because it induces the transition of the lymphoblasts from the G0/G1 phase to $\mathrm{G} 2 / \mathrm{M}$ and $\mathrm{S}$ phases. In addition, heparin might increase the effect of chemotherapeutic drugs on lymphoblasts that are in the $\mathrm{G} 2 / \mathrm{M}$ and $\mathrm{S}$ phases. There are no reports related to the enhancement of chemotherapeutic drug sensitivity by heparin in the treatment of ALL or any type of leukemia. The findings of this preliminary study indicate that further and more comprehensive research on the effects of heparin on the lymphoblast cell cycle is needed to explore the therapeutic potential of heparin in patients with ALL or any kind of leukemia.

\section{Conflict of interest}

No author of this paper has a conflict of interest, including specific financial interests, relationships, and/or affiliations relevant to the subject matter or materials included in this manuscript.

\section{References}

1. Zacharski LR, Ornstein DL, Mamourian AC. Lowmolecular-weight heparin and cancer. Semin Thromb Hemost 2000;26:69-77.

2. Nelson RM, Cecconi O, Roberts WG, Aruffo A, Linhardt RJ, Bevilacqua MP. Heparin oligosaccharides bind Land P-selectin and inhibit acute inflammation. Blood 1993;82:3253-8.

3. Mandal AK, Lyden TW, Saklayen MG. Heparin lowers blood pressure: biological and clinical perspectives. Kidney Int 1995;47:1017-22.

4. Lever R, Page CP. Novel drug development opportunities for heparin. Nat Rev Drug Discov 2002;2:140-8.

5. Borsing L. Antimetastatic activities of modified heparins: selectin inhibition by heparin attenuates metastasis. Semin Thromb Hemost 2007;33:540-6.

6. Smorenburg SM, Van Noorden CJ. The complex effects of heparins on cancer progression and metastasis in experimental studies. Pharmacol Rev 2001;53:93-105.

7. Feng Y, Wu J, Feng X, Tao D, Hu J, Qin J, Li X, Xiao W, Gardner K, Judge SI, Li QQ, Gong J. Timing of apoptosis onset depends on cell cycle progression in peripheral blood lymphocytes and lymphocytic leukemia cells. Oncol Rep 2007;17:1437-44.

8. Eastman A. Cell cycle checkpoints and their impact on anticancer therapeutic strategies. J Cell Biochem 2004;91:223-31.

9. Schmidt M, Bastians H. Mitotic drug target and the development of novel anti-mitotic anticancer drugs. Drug Resist Updat 2007;10:162-81.

10. Dirsch VM, Antsperger DS, Hentze H, Vollmar AM. Ajoene, an experimental anti-leukemic drug: mechanism of cell death. Leukemia 2002;16:74-83.

11. Banker DE, Groudine M, Willman CL, Norwood T, Appelbaum FR. Cell cycle perturbation in acute myeloid 
leukaemia samples following in vitro exposures to therapeutic agents. Leukaemia Res 1998;22:221-39.

12. Carson DA, Wasson DB, Teatle R, Yu A. Specific toxicity of 2- holoradeoxyadenosine toward resting and proliferating human lymphocytes. Blood 1983;62:737-43.

13. Braess J, Jahns-Streubel G, Schoch C, Haase D, Haferlach T, Fiegl M, Voss S, Kern W, Schleyer E, Hiddemann W. Proliferative activity of leukaemic blasts and cytosine arabinoside pharmacodynamics are associated with cytogenetically defined prognostic subgroups in acute myeloid leukemia. Br J Haematol 2001;113:975-82.

14. Duque RE, Andreeff M, Braylan RC, Diamond LW, Peiper SC. Consensus review of the clinical utility of DNA flow cytometry in neoplastic hematopathology. Cytometry 1993;14:492-6.

15. Kaaijk P, Kaspers GJ, Van Wering ER, Broekema GJ, Loonen AH, Hählen K, Schmiegelow K, Janka-Schaub GE, Henze G, Creutzig U, Veerman AJ. Cell proliferation is related to in vitro drug resistance in childhood acute leukemia. Br J Cancer 2003;88:775-81.

16. Riley RS, Mahin EJ, Ross W. DNA ploidy and cell cycle analysis. In: Riley RS, Mahin EJ, Ross W, editors. Clinical Applications of Flow Cytometry. New York, Tokyo: Igaku-Shoin Medical Publisher,1993;271.

17. Tripathi AK, Chaturvedi R, Ahmad R, Asim M, Sawlani KK, Singh MK, Tripathi P, Tekwani BL. Flow cytometric analysis of aneuploidy and S-phase fraction in chronic myeloid leukemia patients: role in early detection of accelerated phase. Leuk Res 2003;27:899-902.

18. Clark GM, Mathieu MC, Owens MA, Dressler LG, Eudey L, Tormey DC, Osborne CK, Gilchrist KW, Mansour EG, Abeloff MD. Prognostic significance of S-phase fraction in good-risk, node-negative breast cancer patients. J Clin Oncol 1992;10:428-32.

19. Pinto AE, Fonceca I, Soares J. The clinical relevance of ploidy and S-phase fraction determination in salivary gland tumors: a flow cytometric study of 97 cases. Cancer 1999;85:273-81.

20. Dean PN. A simplified method of DNA distribution analysis. Cell Tissue Kinet 1980;13:299-308.

21. Wright TC, Johnstone TV, Castellot JJ, Karnovsky MJ. Inhibition of rat cervical epithelial cell growth by heparin and its reversal by EGF. J Cell Physiol 1985;124:490506.

22. Reilly CF, Fritze LMS, Rosenberg RD. Heparin inhibition of smooth muscle cell proliferation. A cellular site of action. J Cell Physiol 1986;129:11-9.

23. Patel RC, Handy I, Patrl CV. Contribution of doublestranded RNA-activated protein kinase towards antiproliferative actions of heparin on vascular smooth muscle cells. Arterioscler Thromb Vasc Biol 2002;22:1439-44.

24. Fedarko NS, Ishihara M, Conrad HE. Control of cell division of hepatoma cells by exogenous heparan sulfate proteoglycan. J Cell Physiol 1989;139:287-94.

25. Wright TC Jr, Pukac LA, Castellot JJ Jr, Karnovsky MJ, Levine RA, Kim-Park HY, Campisi J. Heparin suppresses the induction of c-fos and c-myc mRNA in murine fibroblasts by selective inhibition of a protein kinase C-dependent pathway. Proc Natl Acad Sci USA 1989;86:3199-203.

26. Tiozzo R, Cingi MR, Pietrangelo A, Albertazzi L, Calandra $\mathrm{S}$, Milani MR. Effect of heparin-like compounds on the in vitro proliferation and protein synthesis of various cell types. Arzneim-Forsch 1989;39:15-20.

27. Manaster J, Chezar J, Shurtz-Swirski R, Shapiro G, Tendler Y, Kristal B, Shasha SM, Sela S. Heparin induces apoptosis in human peripheral blood neutrophils. Br J Heaematol 1996;94:48-52.

28. Erduran E, Tekelioğlu Y, Gedik Y, Yıldıran A. Apoptotic effects of heparin on lymphoblasts, neutrophils, and mononuclear cells: results of a preliminary in vitro study. Am J Hematol 1999;61:90-3.

29. Erduran E, Tekelioğlu Y, Gedik Y, Bektaş I, Hacısalihoğlu $\mathrm{S}$. In vitro determination of the apoptotic effect of heparin on lymphoblasts using DNA analysis and measurements of Fas and Bcl-2 proteins by flow cytometry. Pediatr Hematol Oncol 2004;21:383-91.

30. Erduran E, Deger O, Albayrak D, Tekelioğlu Y, Ozdemir T. In vitro investigation of the apoptotic effect of heparin on lymphoblasts by using flow cytometric DNA analysis and fluorometric caspase- 3 and -8 activities. DNA Cell Biol 2007;26:803-8.

31. Kvasnicka HM, Thiele J. Apoptosis and proliferation in the bone marrow of chronic myeloproliferative disorders--biological and prognostic importance. Pathologe 2000;21:55-62.

32. Shapiro GI, Harper JW. Anticancer drug targets: cell cycle and check point control. J Clin Invest 1999;104:1645-53.

33. Dow LW, Chang LJ, Tsiatis AA, Melvin SL, Bowman WP. Relationship of pretreatment lymphoblast proliferative activity and prognosis in 97 children with acute lymphoblastic leukemia. Blood 1982;59:1197-202.

34. Smets LA, Slater R, van Wering ER, van der Does-van den Berg A, Hart AA, Veerman AJ, Kamps WA. DNA index and \%s-phase cells determined in acute lymphoblastic leukemia of children: report from studies ALL V, ALL VI, and ALL VI (1979-1991) of the Dutch Childhood Leukaemia Study Group and The Netherlands Workgroup on Cancer Genetics and Cytogenetics. Med Pediatr Oncol 1995;25:437-44.

35. Harousseau JL. The role of colony-stimulating factors in the treatment of acute leukemia. Bio Drugs 1997;7:448-60.

36. Brach M, Klein H, Platzer E, Mertelsmann R, Herrmann F. Effect of interleukin 3 on cytosine arabinoside-mediated cytotoxicity of leukemic myeloblasts. Exp Hematol 1990;7:748-53.

37. Butturini A, Santucci MA, Gale RP, Perocco P, Tura S. GM-CSF incubation prior to treatment with cytarabine or doxorubicin enhances drug activity against AML cells in vitro: a model for leukemia chemotherapy. Leuk Res 1990;14:743-9.

38. Bai A, Kojima H, Hori M, Nara N, Komeno T, Hasegawa Y, Ninomiya $\mathrm{H}$, Abe T, Nagasawa T. Priming with G-CSF effectively enhances low dose Ara-C induced in vivo apoptosis in myeloid leukemia cells. Exp Hematol 1999;27:259-65.

39. Meister B, Kropshofer G, Klein-Franke A, Strasak AM, Hager J, Streif W. Comparison of low molecular-weight heparin and antithrombin versus antithrombin alone for the prevention of symptomatic venous thromboembolism in children with acute lymphoblastic leukemia. Pediatr Blood Cancer 2008;50:298-303. 